\title{
Assessing the Contribution of Micro Credit Financing to Maize Production in Mezam Division, North West Region of Cameroon
}

\author{
Boris Dinictri Soh Wenda ${ }^{1}$, Dorothy Fon Engwali ${ }^{1}$, Moses Abit Ofeh ${ }^{2,}$ * \\ ${ }^{1}$ Department of Agricultural Economics, Faculty of Agricultural Sciences and Agronomy, University of Dschang, Dschang, Cameroon \\ ${ }^{2}$ Department of Economics, Higher Teacher Training College Bambili, University of Bamenda, Bambili, Cameroon
}

Email address:

bfwenda@yahoo.com (B. D. S. Wenda), dengwali@yahoo.fr (D. F. Engwali), ofeh2002@yahoo.fr (M. A. Ofeh)

${ }^{*}$ Corresponding author

\section{To cite this article:}

Boris Dinictri Soh Wenda, Dorothy Fon Engwali, Moses Abit Ofeh. Assessing the Contribution of Micro Credit Financing to Maize Production in Mezam Division, North West Region of Cameroon. International Journal of Agricultural Economics.

Vol. 5, No. 1, 2020, pp. 9-17. doi: 10.11648/j.ijae.20200501.12

Received: November 23, 2019; Accepted: December 24, 2019; Published: January 9, 2020

\begin{abstract}
This study on the access to micro credits and maize production in Mezam Division, North West Region of Cameroon is aimed at determining the proportion of maize producers having access to credits and identifying the sources of micro credits exploited by maize producers. Using primary data collected from 300 maize producers, analyses were performed through descriptive statistics tools and the Logit model. The findings reveal that $68 \%$ of the respondents have access to credits and the informal sector agents serve as main sources of financing to farmers. The results equally revealed that from the logistic analyses, access to credits, farmers' level of education and farm size among others positively and significantly contribute to maize production. Also, maize producers faced numerous challenges including low and fluctuating prices of maize and poor farm to market roads among others. It is therefore recommended that institutions in charge of providing farmers with financial, technical and commercial assistance should be established within the reach of farmers. That aside, more investments should be made in the construction and maintenance of rural road infrastructures.
\end{abstract}

Keywords: Maize, Credits Access, Logit, Marginal Effects, Cameroon

\section{Introduction}

Cameroon, often referred to as "Africa in miniature" is one of the most diversified countries in Sub-Saharan Africa with respect to its agro-ecology. Thanks to such an environment, major crops peculiar to most African countries such as rice, wheat, barley, maize, cassava, potatoes, plantains/bananas, yams and also cocoa and coffee are produced in Cameroon [5].

Agriculture has been and remains the backbone of Cameroon's economy, employing about $70 \%$ of its workforce, while providing $42 \%$ of its GDP and $30 \%$ of its export revenue $[12,6]$. The main food crops produced are maize, banana, plantains, potatoes, cassava, millet, and sugarcane. In 2004 production of food crops was estimated as follows: sugarcane, 1,450,000 tons; cassava, 1,950,000 tons; sorghum, 550,000 tons; maize, 750,000 tons; millet, 50,000 tons; yams, 265,000 tons; sweet potatoes, 175,000 tons; potatoes, 135,000 tons; dry beans, 95,000 tons; and rice, 62,000 tons [21].

The Government, faced with financial crisis, took steps to boost the production of commodities such as maize, rice, cassava, potatoes, oil palm and plantain. For food crops, these measures aimed at improving the commercialization of products through the construction of warehouses for conservation. In 2009, the agricultural sector accounted for approximately $75.6 \%$ of primary industry with $68.8 \%$ from food crops and $6.8 \%$ from export crops. This sub-sector increased by $8.3 \%$ compared to 2008 , contributing 0.7 percentage point to the growth of the primary sector [23]. However, food production in Cameroon is still largely in the hands of small-holder farmers who make up about $70 \%$ of the farming population [23]. Cultivation practices continue to be characterized by the use of basic tools, small farm size, 
low capital input, high labor inputs, limited control of plant pests and diseases, and low yields [20,21].

Maize is the most widely-grown staple food crop in SubSaharan Africa (SSA) occupying more than 33 million hectares each year and Cameroon is ranked among the top 20 countries accounting for $96 \%$ of the total maize production in SSA along the line with South Africa, Nigeria, Ethiopia, Tanzania, Malawi, Kenya, Zambia, Uganda, Ghana, Mozambique, Mali, Burkina Faso, Benin, DRC, Angola, Zimbabwe, Togo, and Cote d'Ivoire [9]. In Cameroon, maize (Zea mays L.) is not only a staple crop that is consumed as dry fermented dough; it is often also roasted, used as corn porridge and for a large number of other uses. Maize is the highest consumed grain (food stuff) in the country, far ahead of sorghum, rice or wheat [28]. It also provides an economic safety net as much of it can be sold directly or converted into corn beer, which is an important contribution to the local economy in many rural areas [34]. Maize production also serves as a major source of raw materials to some local and sub-regional agro-industries (brewery, feed production, etc.).

Maize is a very strategic crop in Cameroon, in terms of food security and sovereignty [8]. It is the major source of income for more than three million smallholders in Cameroon and it is a reserve currency of smallholders. In family farms, maize occupies a central place and determines the layout of associated crops. Maize is the first ingredient in the manufacture of cattle feed and is indispensable in aviculture accounting for $65 \%$ of the input for manufacturing poultry feed. It also contributes CFAF 5.6 billion to GDP and is regularly consumed by 12 million Cameroonians [21]. Because of its wide climatic adaptability, maize cultivation has expanded rapidly within the country, and the grain has become part of the local diet as a diversification of traditional root crops and various small grains. Maize is cultivated in all the regions of Cameroon. However, the West and the NorthWest regions are the principal zones of maize production; followed by the Adamawa and North regions [2].

Maize production is seen as a crop through which food security and poverty reduction could be achieved in Africa given its fast growth rate of $2.8 \%$ per annum as compared to the world growth rate of $2.5 \%$ [11]. The Central African sub region had the highest growth per annum between 1986 and 2006 of $4.38 \%$ [11]. Despite the increased production, for the past few years, maize production is still unable to satisfy the ever growing national need [19]. African countries in general and Cameroon in particular have been encouraged to boost maize production as one of the ways to achieve the objective of Food security and halving poverty in the continent by 2015 [25]. As a result, maize production has received substantial research, extensive attention and intensification of effort on adoption of improved varieties for improved productivity so as to tackle food insecurity and push the nation towards attaining the objectives of its 2035 Vision.

In spite of the importance of staple food cultivation and the recognition of maize both nationally and regionally, the subsector also suffers from generic constraints observed within Cameroon's agricultural sector (inadequate credits, rudimentary techniques, low rate of productivity, inadequate organization of actors involved, and so on). To remedy the situation, the Agricultural Research Institute for Development (IRAD) has developed efficient varieties of maize seeds to boost maize cultivation. However, maize production has not significantly increased as expected due to lack of credits to galvanize production and Cameroon has evolved from a net exporter of maize in 1974 to a net importer of maize since the 1980 s, accentuating its already negative balance of trade deficit [28].

The study [26] held that there exist three mechanisms for financing agricultural activities via the formal banking financing, the informal financing and the formal microfinance. The activities of the commercial banks (formal sector) are articulated around a model of profitability which is not beneficial to small farmers and craftsmen, and these banks have continuously exploited the rural populations in the vicious circle of poverty [17]. The informal financial system consists of the traders, travelling bankers, the protective sackings "Njangis or Tontines", self-promotion organizations, the usurers, associations and parents/friends/neighbors and is the major source of financing for smallholders. The most significant actor of this informal system is the protective sacking or "Njangis/Tontine". They provide a means for saving as well as financing projects in order to cover the gap left by the banks [17]. Microfinance Institutions (MFIs) constitute the main formal source of finance to small farmers since they do not meet the conditions required to obtain credits from commercial banks [17].

The need to increase agricultural production, to adapt agriculture to the requirements of the market economy and to improve the standards of living of agricultural producers require the development and the adoption of innovations at all the levels of the agricultural value chain (research, production, storage, transformation, and marketing). Such innovations can be diffused into the agricultural system only with the installation of diversified sources of financing adapted to the needs of the agricultural producers as their self-financing capacities alone are not enough. Hence, the limited access of farmers to financial services constitutes one of the major constraints to agricultural development and expansion in Cameroun [26].

Agricultural credit assists farmers to acquire basic tools, new seedlings, transportation and crop preservation mechanisms among others. If one considers the fact that small farmers constitute the bulk of the rural poor in Cameroon, then the importance of credit to them and their activities cannot be over emphasized. Given the financing challenges faced by smallholders and the relevance of maize crop in the nation's economy and local populations' feeding habits, this work questions the various constraints and opportunities for maize production in the Mezam Division, North West Region of Cameroon.

Specifically, this study aims at providing clarity to the following objectives: to determine the proportion of maize producers having access to credits and identifying the sources 
of micro credits exploited by maize producers; to assess the contribution of credits access to maize production and determining the other factors influencing maize production; and to identify the challenges faced by maize producers in Mezam division.

The hypothesis of the study $\left(\mathrm{H}_{\mathrm{o}}\right)$ is that: Access to credits does not contribute to maize production in Mezam Division.

\section{Literature Review}

Considering the socio-economic variations, environmental, climatic and demographic diversities of Cameroon, the potentials for food crop production are quite high. However, the study [22] held that the major constraints to rural development and growth of agriculture are: the falling real prices of agricultural products, the lack of political power of the rural population, the domination of parastatals in the agricultural sector controlling inputs, output markets and access to finance, the shortage of capital, access to knowledge and technology. He also pointed out that the inadequate provision of health and sanitation facilities reduces rural labor productivity and they are inimical to food production. Hence, he proposed that to resolve the problems of productivity in the rural sector, investments should be made in the social infrastructures such as education, health and sanitation; farming infrastructures such as irrigation and extension facilities; exchange infrastructures as market centers and non-market institutions as social networks.

Also, soil fertility decline has been reported as an important problem of food production in the country [16]. Considering soil fertility decline as a constraint to food production in Cameroon, the study [15] in his study concluded that; the use of compost brings an increase in crop yield, leads to lower the crop's irrigation requirements and implies a lower irrigation cost for the farmers. It has also been noticed that; land availability and cost, labor cost, and farmers' socio-economic characteristics as age, gender and farming experience tend to affect farm productivity in developing countries [29]. In the same light, the study [18] then the study [10] revealed that; rural women in SSA in general and Cameroon in particular contribute significantly to agricultural production given that they spend most of their daily time on crop production activities and domestic tasks with little recreation or rest. Therefore, the bulk of the production processes in SSA are carried on by women.

The study [7] noted that crop production with emphasis on maize, is responsive to land use change hence, land availability for cultivation acts as a major constraint to maize production in Cameroon. On the other hand, the study [17] highlighted that; the use of fertilizers and farm sizes positively contribute to small farmers' agricultural productivity. In addition, farm distance and farmers' income levels are other determinants of agricultural production [31].

As indicated by the study [22], access to finance appears to be a significant constraint to agricultural production in developing countries in general and in Cameroon in particular. The study [19] pointed out that about $55.00 \%$ of the maize producers in the North West region of Cameroon had no access to credit. Also, the study [33] stated that the lack of capital in rural areas is one of the major factor which undermines the development of agriculture and was later confirmed by the study [4] which held that; credit has remained a limiting factor to improving agricultural production in Cameroon. This has been confirmed by the study [17] which evaluated the effects produced by micro credits on small farmers' productivity using the Generalized Least Square method of estimation and found that; there is a positive relationship between the access to microfinance credits and small farmers' agricultural productivity. The study [35] revealed that farmers using micro credits are much more efficient than those who do not use micro credits meanwhile the study [1] found out that the major constraint to maize production in West Cameroon is poor access to credits facilities. Whereas the study [25] held that micro loans and agricultural educational schemes/programs significantly influence the probability of having low or higher post-harvest yield.

However, the study [32] analyzed the factors that determine productivity of fruit and vegetable growers in Central Chile and came out with findings indicating that short-term credit does not have an impact on farm productivity but other factors as education has an impact on farm productivity. It is based on the above revelations and findings by various authors that this study comes into assessing the constraints and opportunities of maize production in Mezam division of the North West Region of Cameroon.

\section{Materials and Methods}

\subsection{Area of Study}

Mezam is one of the seven administrative divisions of the North West Region of the Republic of Cameroon. The Mezam division has as head town Bamenda and covers a land surface of $1,745 \mathrm{~km}^{2}$. It is located between latitudes $5^{\circ} 20^{\prime}$ and $6^{\circ} 15^{\prime} \mathrm{N}$ and longitudes $09^{\circ} 7^{\prime}$ and $10^{\circ} 21^{\prime} \mathrm{E}$. According to the 2005 population and housing census, Mezam has a population of about 566,921 inhabitants giving a population density of 324.9 inhabitants per $\mathrm{km}^{2}$ [24]. It is composed of seven subdivisions: Bafut, Bali, Bamenda 1, Bamenda 2, Bamenda 3, Santa and Tubah.

The study area is characterized by a cool temperate-like climate, influenced mainly by mountainous terrain and rugged topography. Average rainfall is about $2,400 \mathrm{~mm}$, temperature average $23^{\circ} \mathrm{C}$, ranging between $15^{\circ}-32^{\circ} \mathrm{C}$. There are two main seasons; wet/rainy season, which starts in March and ends in October, and dry season from November to February. The dry season is characterized by the harmattan dry air [30]. The climatic conditions of the area are favorable for agricultural practices and three types of soils exist in the area namely: volcanic, hydromorphic and ferrallitic soils.

The economy of the region and that of Mezam division in 
particular is predominantly agricultural. According to the study [13] more than $80 \%$ of the rural population depends solely on agriculture, including a strong livestock sub-sector. Food crops include Maize (Zea mays L), rice (Oryza sativa), potatoes (Ipomoea batatas), and beans (Phaseolus vulgaris). Plantains (Musa sapientum), cocoyams (Colocasia esculenta), cassava (Manihot esculenta) and yams (Dioscorea spp) are also produced, and many of these are food staples in the region.

Maize which is one of the major food crops is cultivated by almost all the households in this area. Three improved maize varieties are cultivated in this area; Coca white, Kasai and ATP with the latter being the most widely cultivated [19]. However, the PANA variety has also been introduced in the past years and is recognized for its very high yield.

\subsection{Data Collection}

The data used for this study are all of primary source and were collected through the use of interviews and a well-structured questionnaire. The study focused on maize farmers in the Mezam division of the North West region who are estimated to be about 1000 in number. A multistage random sampling technique was used to select the respondents. At the first stage, there was a random selection of two sub-divisions in Mezam (Tubah and Bafut). Secondly, for each of the two sub-divisions, three villages were randomly selected namely; Bambili, Sabga and Bambui in Tubah out of 11 villages; Mankwi, Bawum and Mantaa in Bafut out of 17 villages. This gives a total of six villages for the study. In the third stage, 50 maize producers were randomly selected from each of the six villages. This gave a total of 300 respondents who provided answers to the questionnaire.

\subsection{Data Analysis}

The analytical tools adopted in this study consisted of both descriptive and inferential methods of analysis. The descriptive statistics made use of percentages, frequency tables, measures of central tendency and pie charts. The inferential statistics consisted of the use of econometric regression techniques and the specific technique used was the Logistic regression.

\subsubsection{Realization of Objectives}

Descriptive statistic tools were used to determine the proportion of maize producers having access to credits and identify the sources of micro credits exploited by maize producers; and to identify the challenges faced by maize producers in Mezam division. Whereas, to assess the contribution of credits access to maize production and determine the other factors influencing maize production, the logistic regression was applied.

\subsubsection{Model Specification}

In this study, the economic model of the family developed by the study [3] was used to quantify the effects of credit access on maize production in Mezam division. Following the study [27] and for convenient reasons, mainly the ease of manipulation of the function, the logistic model was preferred over the probit model. Hence, the general form of the model estimated is as follows:

$$
\mathrm{MP}_{\mathrm{i}}=\mu_{0}+\lambda_{1} \chi_{\mathrm{i}}+\delta_{1} \mathrm{AC}_{\mathrm{i}}+\varepsilon_{1}
$$

Where $\mathrm{MP}_{\mathrm{i}}$ is a binary variable representing family $i$ 's participation in maize production, $\chi_{i}$ is a vector/set of family characteristics (family size, age, marital status, level of education of family head, sex of family head, income, other activity,) and farm/farming characteristics such as; farm size, experience in farming, fertilizer usage, source of man power, training in agriculture, farming system and seeds used. The $\mathrm{AC}_{\mathrm{i}}$ is Access to credit which can possibly be obtained from different sources such as banks, micro financial institutions, "njangis"/ROSCAS, friends and family members as well as support from government and other donor institutions, $\varepsilon_{\mathrm{i}}$ is a random error term and the intercept is represented by $\mu_{\mathrm{i}}$. The coefficient $\delta_{\mathrm{i}}$ is the parameter of primary interest and represents the impact that credit access has on maize production.

The selection of variables to be used in this study was mainly done based on existing literature. They have their pertinence due to the historical role they have played in the development and expansion of agriculture (farm size, access to credit, fertilizer used, seeds used and training in agriculture). Also, some of the variables were selected based on the indirect effect they have on farming activities such as (other economic activities, farmers' level of education and family size).

The regression was conducted with the mode of Robust Standard Error (RSE) because this mode deals with minor problems such as; minor deviations from normality, autocorrelation, heteroskedasticity, multicollinearity and observations exhibiting large residuals $[27,14]$.

Also, the marginal effects were computed. The marginal effect of a variable $\chi$ is the average of the marginal effect of everyone in the sample, thus;

$$
M E\left(\chi^{K}\right)=\frac{1}{N} \sum_{i} \frac{\delta P\left(M P_{i}=\mid \chi_{i,} A C_{i,} \hat{\beta}, \hat{\lambda}, \hat{\delta}\right)}{\delta \chi_{i}^{k}}
$$

Where $\chi_{i}$ is a vector of characteristics with $\chi_{i}^{k}$ the $\mathrm{k}$ 'th element in that vector, thus, the marginal effect of credit access on maize production is:

$$
\mathrm{ME}=\left((\chi)=1 / \mathrm{N} \sum\left(\mathrm{P}\left(\mathrm{MP}_{\mathrm{i}}=1 \mathrm{AC}_{\mathrm{i}}=1\right)-\mathrm{P}\left(\mathrm{MPi}=1 \mathrm{AC}_{\mathrm{i}}=0\right)\right)\right.
$$

Table 1. Variables of study.

\begin{tabular}{llc}
\hline Variables & Description & Expected Sign \\
\hline Explained variable & & \\
Maize output level & Binary variable for output level. $0=$ Low; $1=$ High & Not available \\
\hline
\end{tabular}




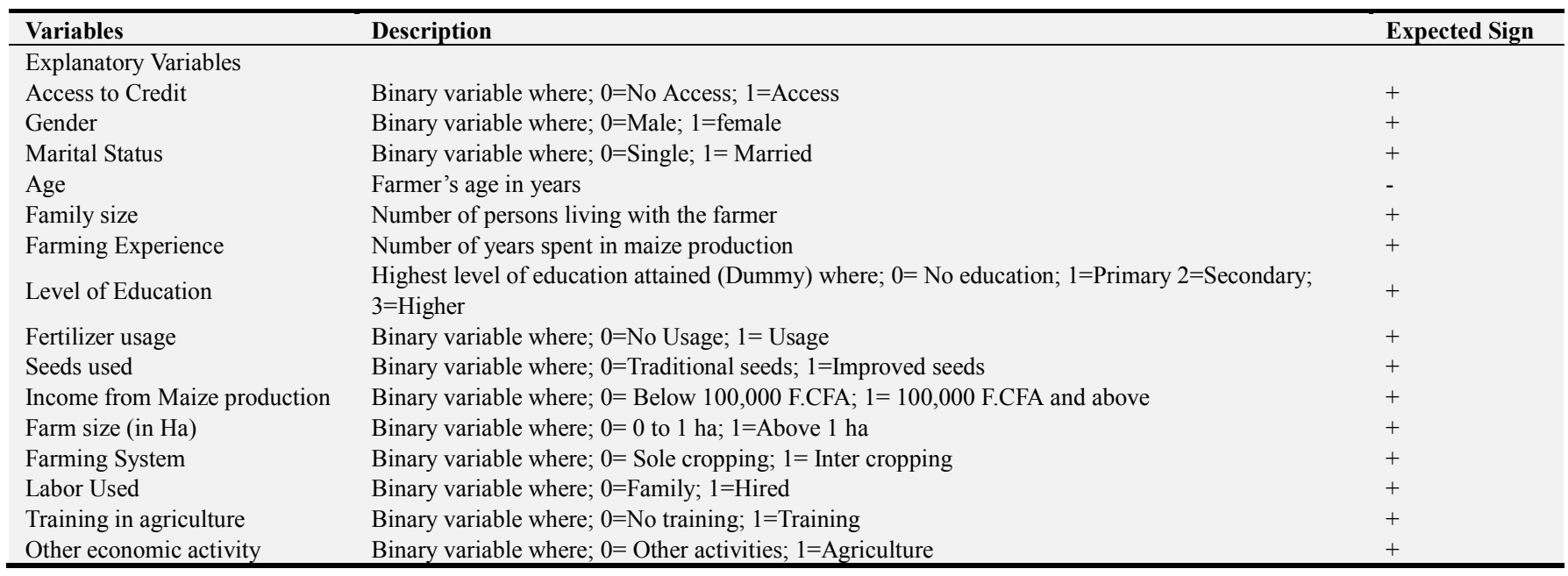

The variables used in the model, their measurements and their expected signs are presented in table 1.

\section{Results}

\subsection{Socio-Economic Characteristics of the Respondents}

Farmers' socio-economic characteristics have been established as factors relevant in determining farm productivity. Therefore, an analysis of these characteristics is an essential step to take in any study where farmers and their productive abilities are involved. The respondents' socio-economic characteristics are analyzed and presented in table 2.

Table 2. Farmers' Socio-Economic Characteristics.

\begin{tabular}{|c|c|c|c|c|}
\hline \multicolumn{5}{|c|}{ Gender of Maize Producers (\%) } \\
\hline Male & & Female & & Total \\
\hline 51.67 & & 48.33 & & 100 \\
\hline \multicolumn{5}{|c|}{ Age Distribution of Maize Producers in complete years (\%) } \\
\hline Less than 40 & $40-50$ & $51-60$ & Greater than 60 & Total \\
\hline 24.67 & 14.33 & 38.33 & 22.67 & 100 \\
\hline \multicolumn{5}{|l|}{ Marital Status (\%) } \\
\hline Single & & Married & & Total \\
\hline 24.33 & & 75.67 & & 100 \\
\hline \multicolumn{5}{|c|}{ Level of Education (\%) } \\
\hline No education & Primary & Secondary & Tertiary & Total \\
\hline 3.33 & 48.67 & 40.33 & 7.67 & 100 \\
\hline \multicolumn{5}{|c|}{ Family Size (Number of persons) (\%) } \\
\hline Less than 5 persons & 5-10 persons & More than 10 persons & & Total \\
\hline 28 & 65.33 & 6.67 & & 100 \\
\hline \multicolumn{5}{|c|}{ Farming Experience in years (\%) } \\
\hline Less than 10 years & $10-20$ years & $21-30$ years & More than 30 years & Total \\
\hline 23.00 & 22.33 & 48.33 & 6.33 & 100 \\
\hline \multicolumn{5}{|c|}{ Training in Agriculture } \\
\hline No training & & Had Training & & Total \\
\hline 52.00 & & 48.00 & & 100 \\
\hline \multicolumn{5}{|c|}{ Other Income Generating Activity (\%) } \\
\hline Business & Civil Servant & Agriculture & Others & Total \\
\hline 47.67 & 11.67 & 34.33 & 6.33 & 100 \\
\hline \multicolumn{5}{|c|}{ Net Income From Maize Production (\%) } \\
\hline Less than $100,000 \mathrm{~F}$ & & $100,000 \mathrm{~F}$. CFA and more & & Total \\
\hline 39.67 & & 60.33 & & 100 \\
\hline
\end{tabular}

Upon data collection and analysis, it was revealed that; $51.67 \%$ of respondents are male and $48.33 \%$ are female; only $24.67 \%$ of the respondents are aged of below 40 years implying that maize production is mostly dominated by the old; however, $75.67 \%$ are currently married whereas, only $24.33 \%$ of the respondents are single and this category includes the widow (er), divorced and those that were never married. Added to the above, the findings indicated that; only $3.33 \%$ of the respondents had undergone no formal education against $96.67 \%$ that had undergone at least primary education. Also, only $28 \%$ of the sampled maize producers had family sizes of less than 5 persons about, only $23 \%$ had been engaged into maize production for less than 10 years, only $48 \%$ had 
undergone training in agriculture, $34.33 \%$ were full time farmers and only $39.67 \%$ of the respondents earned on

\subsection{Access to Credits and Sources of Credits Exploited by Maize Producers}

This study sought among others to determine the average less than 100, $000 \mathrm{~F}$. CFA from the production of maize each season.

proportion of maize producers having access to credits and the various sources they obtain these credits. The results obtained from these analyses are presented in table 3.

Table 3. Distribution of Respondents According to Credit Access and Sources of Credit.

\begin{tabular}{|c|c|c|c|c|}
\hline \multicolumn{5}{|c|}{ Access to Credits (\%) } \\
\hline Yes & & No & & Total \\
\hline 68 & & 32 & & 100 \\
\hline \multicolumn{5}{|c|}{ Sources of credits Exploited (\%) } \\
\hline Friends/Family & Njangis /ROSCAS & Cooperatives and MFIs & Government Institutions & Total \\
\hline 26.99 & 27.68 & 43.6 & 1.73 & 100 \\
\hline
\end{tabular}

Going by the results presented in table 3 , it is observed that a significant majority of the respondents $(68 \%)$ had access to credits whereas only $32 \%$ had no access to credits for their farming activities and therefore depend solely on household generated income to invest as capital in agricultural production. Also, the results indicated that $26.99 \%$ of the respondents obtain credits mainly from friends and family members, $27.68 \%$ from ROSCAS (Njangis), 43.6\% from cooperatives and microfinance institutions and only $1.73 \%$ from government institutions. Hence, the informal sector (Friends /Family members and "Njangis") is the dominant agent that provides financial services to farmers by serving as the main source of credits to a total of $54.67 \%$ of the respondents. This is due to the ease of access to credit from these sources, that is the absence of administrative procedures and most often lower interest rates and absence of tangible collateral applied in these outlets.

\subsection{Credit Access and Other Correlates of Maize Output}

Having established the relevance of credit access to agricultural production in Cameroon in the literature, a logistic regression was used to determine the contribution of credits access and other correlates (age, farm size, farming experience) to maize production in the area of study. The results obtained are presented in table 4 .

The results obtained here depict the existence of a positive and significant relationship between credit access and maize output level with an odd ratio and marginal effect of 2.80 and 0.11 respectively. The odd ratio value of 2.8 implies that the odds in favor of having high output levels is 2.8 times greater for farmers having access to credits than for those without access to credits. Meanwhile the marginal effect of 0.11 implies that as farmers move from no credit access to credit access, the probability of having high yields or output levels increase by 0.11 . Therefore, the probability of having high output levels for farmers obtaining credits is greater than that of those having no credit access by 0.11 and this result is statistically significant at 5\% level.

Other correlates of maize production highlighted by the study include labor used, famers' level of education, farm size, fertilizer usage, farming system, seeds used, other economic activities and income from maize production. However, of all the above factors, only the type of seed used has a negative effect on maize output level.

The goodness of fit measured with the Pseudo R2 stands at 0.4804 and the results have their overall significance at $1 \%$ level with a Wald chi2 of 105.12 and a probability value (Prob $>$ chi2) of 0.0000 .

Table 4. Factors influencing Maize Output level.

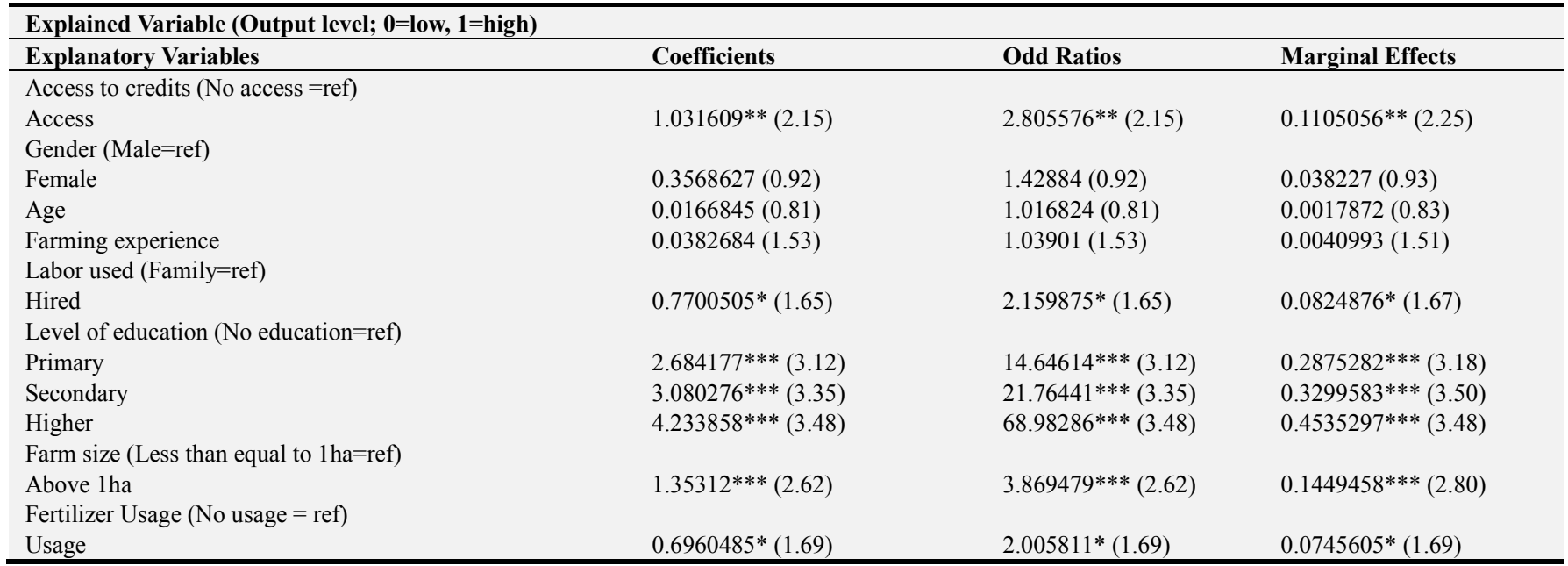




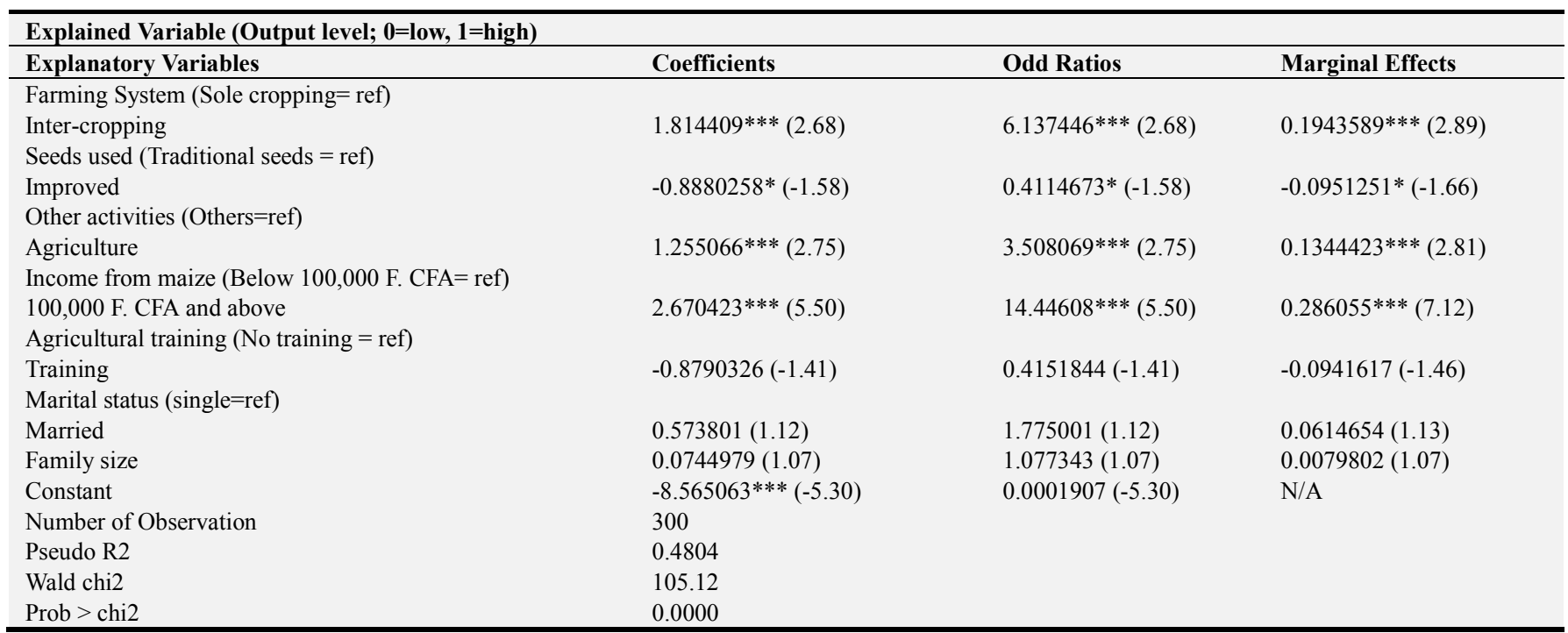

Note: $* * * * *$ and $*$ indicate $1 \%, 5 \%$ and $10 \%$ significance levels, respectively;

ref reference category; $\mathrm{N} / \mathrm{A}=\mathrm{Not}$ applicable; $\mathrm{t}$-statistics in parentheses.

\subsection{Challenges Faced by Maize Producers}

Results for challenges faced by maize producers are summarized and presented in table 5 .

Table 5. Challenges faced by Maize Producers.

\begin{tabular}{lll}
\hline Lack of fertilizer input & & \\
\hline Agree (\%) & Disagree (\%) & Total \\
55.33 & 44.67 & 100 \\
Low Yielding Seeds & & \\
Agree (\%) & $\begin{array}{l}\text { Disagree (\%) } \\
45.33\end{array}$ & Total \\
Farm to Market Roads & 54.67 & \\
Agree (\%) & Disagree (\%) & Total \\
84.33 & 15.67 & 100 \\
Low and Fluctuating Prices & & \\
Agree (\%) & Disagree (\%) & Total \\
92.33 & 7.67 & 100 \\
Storage Facilities & & \\
Agree (\%) & Disagree (\%) & Total \\
41.67 & 58.33 & 100 \\
Lack of Financial Capital & & \\
Agree (\%) & Disagree (\%) & Total \\
52.33 & 47.67 & 100 \\
Lack of Training & & \\
Agree (\%) & Disagree (\%) & Total \\
45.33 & 54.67 & 100 \\
Weather and Climatic Challenges & & \\
Agree (\%) & Disagree (\%) & Total \\
87.67 & 12.33 & 100 \\
\hline
\end{tabular}

By order of priority and based on the proportion of farmers who agree with each option, the challenges faced by the farmers are; low and fluctuating prices with $92.33 \%$; weather and climatic changes with $87.67 \%$; poor nature of farm to market roads with $84.33 \%$; lack of fertilizer inputs with $55.33 \%$; lack of financial capital with $52.33 \%$; seed used and lack of training in agriculture with $45.33 \%$ each; and poor storage facilities with $41.67 \%$.

\section{Discussions}

The results obtained from the study revealed that; $68 \%$ of the sampled maize producers in Mezam division have access to credits. This result is slightly different from the findings of the study [19] who pointed out that about $55.00 \%$ of the maize producers in the North West region of Cameroon had no access to credit. The same findings indicate that; the informal sector (Friends /Family members and "Njangis") is the dominant agent that provides financial services to farmers by serving as the main source of credits to a total of $54.67 \%$ of the respondents and ROSCAS (Njangis) is the dominant agent of the informal sector; $43.6 \%$ of the respondents obtained credits from cooperatives and microfinance institutions whereas only $1.73 \%$ obtained credits from government institutions.

These findings corroborate those of Kendo et al., (2014) who noted that; the most significant actor of the informal financial system is the protective sacking or "Njangis/Tontine"; and that microfinance is the major actor of the formal financial sub-sector so far as the financing of farmers' activities is concerned. The findings are also in line with the results of the study [27] which revealed that small holders in majority seek for credits in the informal sector.

Moreover, credit access has a positive and significant effect on maize output level. This is possible due to the fact that; farmers with access to credits can have access to larger farms through renting, they can support the cost of hiring a larger and more efficient work force and the credits can enable them acquire modern and more efficient production equipment and inputs. This is contradictory to the findings of the study [32] who analyzed the factors that determine productivity of fruit and vegetable growers in central Chile and came out with findings that short-term credit does not have an impact on farm productivity.

However, the result is in conformity with those of the study [17] who came to the conclusion that there is a positive 
relation between the access to microfinance credits and small farmer's agricultural productivity, the study [35] found out that farmers using the micro credits are much more efficient and improve their incomes faster as compared to those who do not use micro credits in Bangladesh. Lastly, the study [1] in West Cameroon found that the major constraint to maize production was poor access to credit facilities. The result of this study enables us to confirm the assertion made by; the study [22] which held that access to finance appears to be a significant constraint to agricultural production in developing countries in general and in Cameroon in particular; the study [33] which stated that the lack of capital in rural areas is one of the major factors which undermine the development of agriculture and; that credit has remained a limiting factor to the improvement of agricultural production in Cameroon [4].

Other correlates of maize production are level of education, farm size, labor used, other economic activities, income from maize production and fertilizer usage, farming system and seeds used. These results are in line with those of; the study [32] which came to the conclusion that other factors for instance education has an impact on farm productivity; the study [15] who held that the use of compost brings an increase in crop yield; the study [17] who noted that added to access to credits, farm size has a positive influence on the agricultural productivity of the small farmers. Also, the study [7] highlighted that maize production in Cameroon is responsive to land use change (forest area change); the study [29] held that land availability tends to affect farm productivity in developing countries; and the study [31] indicated that some major determinants of agricultural production (yam production) performance in their study conducted in Nigeria are farm distance and income level of the farmers.

\section{Conclusions}

After investigations and analyses, the study concludes that in spite of the numerous sources of credit at the disposal of small farmers, some are still not making use of these outlets to finance their farming activities and the informal sector remains the most dominant rural financial agent in the area of study. However, MFIs and cooperatives are gaining more ground in the area of study as rural financial agents. Also, added to financing challenges, farmers in general and maize producers face several challenges in their day to day farming activities. Therefore, given the positive and significant contribution of credit access to maize production, access to credit can be considered as one of the empowerment tools with the potential of boosting farm productivity, increase food security and change the life style of farmers in the long run.

Considering the relevance of maize in the feeding habits and economic life of the Mezam population and North West as a whole, the following recommendations are made:

Producers should be less reluctant in taking the risk of borrowing money for farming purposes. They should mobilize themselves and form cooperative and create village banks in order to mobilize their resources and better coordinate their activities. The youths should get more involved in farming to fully exploit the agricultural potentials of Mezam since most farmers are old. Governmental organizations in charge of providing financial, technical and commercial assistance to farmers should be established at the reach of farmers to enable them fully benefit from their supports. Equally, the local authorities should invest more in the development and maintenance of rural road infrastructures.

\section{References}

[1] Abu, G. A., Djomo-Choumbou; R. F., and Okpachu, S. A., (2011). Evaluating the constraints and opportunities of maize production in the west region of Cameroon for sustainable development. Journal of Sustainable Development in Africa, Vol 13, No. 4. P. 189-196.

[2] AGRISTAT (2009). Annuaire Statistique du secteur Agricole campagne 2006-2007. DESA, MINADER Cameroun.

[3] Becker, G. (1965). A theory of the allocation of time. The Economic Journal 75 (299): 493-517.

[4] Bime, M.-J., and Mbanasor, J. A. (2011). Analysis of rural credit market performance in North West region, Cameroon. Agris on-line Papers in Economics and Informatics Volume III Number 3, 2011 pp 23-28.

[5] Besong, M. T., Bakia, B. and Chidebelu, S. A. N. D. (2009). Farming Systems Research and Extension in Developing Economies: Experiences with Low Resource Farmers in South West Cameroon, Serials Publications, New Delhi, India.

[6] Direction des Enquêtes et Statistiques Agricoles (DESA), (2009). Annuaire des statistiques du secteur agricoles campagnes 2006-2007; MINADER/DESA/ AGRISTAT N ${ }^{\circ}$ 15 Ministère de L'Agriculture et du Développement Rural (MINADER): Yaoundé, Cameroun, 2009; p. 111.

[7] Epule, E. T. and Robin, B. C. (2014). Maize production responsiveness to land use change and climate trends in Cameroon. Journal of Agricultural Sustainability, Open Access at www.mdpi.com.

[8] Etoundin, S. M. (2007). Analyse de l'impact de l'innovation sur la productivité agricole: cas du maïs dans la province du centre Cameroun"; Mémoire de DEA-PTCI, Université de Yaoundé II- Soa, Cameroun.

[9] FAOSTAT (2014). Food and Agriculture Organization of the United Nations Statistical Database. http://www.faostat.fao.org; Accessed on 06 September 2015, Rome, Italy: Food and Agriculture Organization of the United Nations.

[10] Fon D. and Edokat T. (2012): Marginalization of Women's Role in Sub-Saharan Africa towards Crop Production: A Review, Agricultural Science Research Journals, Vol. 2 (9), pp. $499-505$.

[11] Forum for Agricultural Research in Africa (FARA), (2006). Framework for African agricultural productivity: Cadre pour la productivité agricole en Afrique. Accra, Ghana. p. 72. 
[12] Institut National de la Statistique (INS), (2008). Institut National de la Statistique: Rapport national de progrès des objectifs du millénaire pour le développement; l'Institut National de la Statistique du Cameroun (INS), MINRESTINS/PNUD-2008, Yaounde, Cameroon, 2009; p. 36 .

[13] Institut National de la Statistique (INS), (2010). Annuaire Statistique du Cameroun 2010.

[14] Jann, B. (2012). Robust Regression in STATA: $10^{\text {th }}$ German STATA user Group Meeting. Berlin, June 1, 2012.

[15] Jaza, F. A. J. (2007). The use of compost for the cultivation of foodstuff crops and vegetables in the villages surrounding Yaoundé (Cameroon): descriptive and production function approaches of analysis. Quarterly Journal of International Agriculture 46 (2007), No. 3: P. 221-239.

[16] Kanmegne, J., Smaling, E. M. A., Brussaard, L., GansopKouomegne, A., and Boukong, A. (2006). Nutrient flows in smallholder production systems in the humid forest zone of southern Cameroon. Nutrient Cycling in Agroecosystems 76: 233-248.

[17] Kendo, S., Yaya, S. et Ntsama, M. (2014). Impacts des services de microfinance sur la productivité des microagriculteurs au Cameroun. Dans Ayuk, E. T. et Kwabena O. A. (Eds) La Microfinance en Afrique Centrale: le Defi des Exclus. Bamenda, Cameroun Langaa RPCIG.

[18] Logo, P. and Bikie, E. (2003) Cameroon: overcoming custom, discrimination and powerlessness. In women and land in Africa: culture, religion and realizing women's right, ed. M. L. Wanyeki London: Zed Books Ltd. Pp. 281-287.

[19] Manu, I. N., Tarla, D. N., and Chefor, G. F., (2014). Effects of improved maize (Zea mays L.) varieties on household food security in the North West Region of Cameroon. Scholarly Journal of Agricultural Science Vol. 4 (5), pp. 265-272 May, 2014.

[20] Ministère de l'Agriculture et du Développement Rural (MINADER), (2005). Evolution des productions agricoles au Cameroun au cours de la dernière décennie (1993/94 2003/04). Actions menées et mesures envisagées. Rapport d'étude.

[21] Ministère de l'Agriculture et du Développement Rural (MINADER), (2006). Stratégie de Développement du Secteur Rural: Synthèse du volet agriculture et développement rural. Document de travail, République du Cameroun.

[22] Molua, E. L. (2002). Rural development and agricultural progress: Challenges, Strategies and Cameroonian Experience. Discussion papers, Institute of Rural Development, University of Goettingen, Germany.

[23] National Institute of Statistics (NIS), (2010). The population of Cameroon: Reports of presentation of the final results of the 3rd General Census of Population and Habitats (RGPH): Central Bureau of Census and Population Studies (BUCREP), National Institute of Statistics of Cameroon (INS), Ministry of Economy and Finance, Yaounde, Cameroon.

[24] Ngoe, F., Nzino, M. V., Bissaya, B. E., and Fosso, S. R., (2015). The field work study report of the North West Region Team (Mezam Division). In the Framework of the Project Carried on the Evaluation of the Non Achievement of the Millenium Development Goals In Cameroon. Field work report carried out from July $06^{\text {th }}$ to $10^{\text {th }} 2015$ in the Mezam Division, North West Region of Cameroon.

[25] Njimanted, G. F., Mbohjim, O. M., and Dinah, G. P. (2014). MIDENO's schemes as agent of rural agricultural development: The case of maize production in Mezam division, Cameroon. Journal of Agricultural Economics, Extension and Rural Development: Vol. 2 (6): pp 085-093.

[26] Nonga, N. F., Mbog, N. et Bikomem M. L. (2009a). Demande de financement des exploitations agricoles dans le grand sud du Cameroun. Dans Ayuk, E. T. et Kwabena O. A. (Eds) la microfinance en Afrique Centrale: le Defi des Exclus. Bamenda, Cameroun Langaa RPCIG, 2014.

[27] Nonga, N. F. Zonkeng, G. C. Havard, M. Nlom, J. H. Modjeli, N. Kouodiekong, L. Mafouasson, H. Essomba, J. M. Minkoua Nzie, J. R. et Guemne, Th. (2009b). Analyse de la diversite des exploitations familiales agricoles à base de mais dans le Centre et à l'Ouest du Cameroun. Rapport d'analyse des données globales d'enquete. Ydé, PRP OP Mais/REPARAC/IRAD, 103p.

[28] Ntsama, E. and Epo, N. B. (2009). Gender, agricultural crisis, innovatory choice and profitability in maize cultivation in Cameroon. Paper presented at DSA Annual Conference 2009: Contemporary Crises and New Opportunities, University of Ulster, Coleraine Campus, Wednesday September 2nd Friday September 4th 2009.

[29] Nwaiwu I. U., Ohajiaya, D. O., Orebiyi J. S., Obasi, P. C., Lemchi, J. I., Ibekwe, U. C., Onyeagocha, S. U. O., Ukoha, I. I., Osuji, M. N., and Kadiri, F. A., (2012). Socio-economic determinants of the productivity of garden egg (Solanum Melongena) farmers in Imo State, South East Nigeria. International Journal of Agriculture and Rural Development. Volume 15 (2): pp123-128.

[30] Olayiwola, A. M., Eludoyin, A. O, and Ekecha, A. E., (2011). Land Use Change in the Mezam Division of the North-West Province, Cameroon from Landsat Imageries (1988 And 2001). Ethiopian Journal of Environmental Studies and Management Vol. 4 No. 12011.

[31] Oluwatusin, F. and Shittu, G. (2014). Effect of socioeconomic characteristics on the farm productivity performance of yam farmers in Nigeria. Research on Humanities and Social Sciences www.iiste.org Vol. 4, No. 6, 2014.

[32] Reyes, A., Lensink, R., Kuyvenhoven, A., and Moll, H. (2012). Impact of access to credit on farm productivity of fruit and vegetable growers in Chile. Selected Poster prepared for presentation at the International Association of Agricultural Economists (IAAE) Triennial Conference, Foz do Iguaçu, Brazil, 18-24 August, 2012.

[33] Tefera, D., (2004). Determinants of Smallholder Farmers Demand for no Form Credit: the case of Falta Woreda, Alemaya University, Ethiopia.

[34] Tingem, M., Rivington, M. and Colls, J. (2008). Climate variability and maize production in Cameroon: Simulating the effects of extreme dry and wet years. Singap. J. Trop. Geogr. 2008, 29, 357-370

[35] Wadud, M. A. (2013). Impact of microcredit on agricultural farm performance and food security in Bangladesh: Institute of Microfinance Working Paper No. 14. Dhaka, Bangladesh. 